\title{
A cross-sectional study on the nutritional status and morbidity profile of tribal and non-tribal female brick-field workers of Paschim Medinipur district
}

\begin{abstract}
:
Objective: The aim of the present study was to investigate the socioeconomic, anthropometric status and health morbidity profile of tribal and non tribal female brick-field workers of Paschim Medinipur district. Study design: Assessment of socioeconomic, health and nutritional parameters were done using 300 tribal \& non tribal brick-field female workers at the age group of 18-30 years after randomized sampling. Place and duration of study: The study was done in 30 brick-fields located in Paschim Medinipur district of West Bengal in the month of November and December, 2013 for a period of 60 days. Methodology: Through oral questionnaire methods, socioeconomic studies, health morbidity profile and dietary assessments were performed. Anthropometric parameters were measured by the conventional anthropometric methods. Results: From the study it was observed that most of the women workers were illiterate. Female workers of non tribal and tribal groups engaged in this industry were living below the poverty line and the tribal workers showed poor economic status than the non-tribal women workers. The female workers showed significant decrease in height, weight and body mass index, compared to the Indian national standard values. Mid upper arm circumference (MUAC) and waist-hip ratio (WHR) was also significantly lower to the Indian national standard in both age groups of female workers. The intake of energy, protein, carbohydrate carotene, riboflavin, dietary fiber, calcium and iron were significantly lower compared to the standard ICMR RDA. Conclusion: The female workers engaged in brick manufacturing works are mostly illiterate, economically backward, which make them vulnerable to health insecurity. Malnutrition among tribal \& non tribal female workers is a problem that has perhaps been under-recognized, and should now take greater priority.
\end{abstract}

Key Words: Tribal; Non-tribal; Nutritional; Anthropometric parameters; Morbidity.

\section{Sujata Maiti Choudhury, Prasan} Sabud, Pralay Maity, Madhubanti Bepari and Ananya Pradhan

Department of Human Physiology with Community Health, Vidyasagar University, Midnapore- 721102, West Bengal, India

Corresponding Author: Dr. Sujata Maiti Choudhury Email: smaitichoudhury@yahoo.com

(c) 2014 IJOSH All rights reserved.

\section{Introduction}

The Indian brick industry is the second largest in the world, employing huge numbers of migrant workers counting men, women and children. Brick-field workers are recognized for poor health and deprived access to health care. They are prone to malnutrition and specialized group of diseases. Nearly $50 \%$ of the workers in this industry are women. The wages of women in the brick industry are only about half of the wages earned by men for those works which are not physically less strenuous than that of men [1, 2]. Actually, women are employed solely for carrying head loads, whereas all skilled and semi-skilled work such as moulding, shaping and stacking is done by men only. When the turnover of a brick-making company tends to reduce, excessive pressure comes to the workers [3]. In West Bengal the months from July to October are considered as the rainy season. Throughout the rainy season the brick manufacturing usually remains stopped. November to March is the pick season for brick making. That is why the brick field workers either engage themselves in cultivation or remains unemployed for the rest of the year. New generation's men are not interested in farming; hence the demand of female worker in farming is increasing day by day. In the milieu of the new economics of liberalization and its challenges to work, human health security and development, it is necessary to appreciate whether working women in unorganized sector are in a position to take advantage of the economic take-off. Better health and nutrition can increase household income and economic growth in view of the fact that healthy female workers have better intellectual and working capacities. III health will consequently in a loss of working days or in reducing working capacity. In the 
multi-ethnic society in India. there are 400 odd distinct communities which are designated as tribes. Their place in society and in politics of the country is no less imperative than other groups or collective entities. In India, besides the non tribal women, the health status of the tribal population is known to be underprivileged. The extensive poverty, illiteracy, malnutrition, absence of safe drinking water, improper sanitary and living condition, poor maternal and child health services have been drawn out in several studies as possible causative factors for despairing health conditions predominating among tribal populations. The majority of the female labourers of the brick field come from the tribal areas. A women's health affects the household economic well-being since a woman with poor health will be less productive in the labour force. The workers have poor access to health care. They are at possibility of various types of illnesses [4]. Therefore, this present study was designed to evaluate socioeconomic, anthropometric status as well as morbidity profile of tribal and non-tribal female brick-fieldworkers of Paschim Medinipur district.

\section{Methods}

The study has been done in the month of November and December 2013 on 30 brick-fields located in Paschim Medinipur district of West Bengal, India. Data were collected randomly from 300 tribal \& non tribal female workers in the age group of 18-30 years working in these brick-fields.

\section{Socio-economic parameters:}

Through an oral questionnaire method, data of socio-economic parameters like education and family income were collected.

\section{Morbidity parameters}

The data on morbidity (recent illness, present complaints relating to nutrition) were assessed by oral questionnaire method.

\section{Anthropometric parameters:}

Measurements of Height and Weight: Measurements of height and weight of each subject were taken by the standard techniques [5]. Height and weight measurements were recorded to the nearest $0.1 \mathrm{~cm}$ and $0.5 \mathrm{~kg}$ respectively.

Body Mass Index (BMI): Weight $(\mathrm{kg})$ / Height $(\mathrm{m})^{2}$. It was evaluated using internationally accepted BMI guidelines of the World Health Organization [6]. The following cut-off points were used:

CED Grade III: BMI < 16.0

CED Grade II: BMI $=16.0-16.9$

CED Grade I: $\mathrm{BMI}=17.0-18.4$

Normal: $\mathrm{BMI}=18.5-24.9$

Overweight: $\mathrm{BMI} \geq 25.0$.

Mid upper arm circumference (MUAC): MUAC is measured to designate the status of muscle development. It is worthwhile to identify malnutrition and the morbidity threat of the human being. $22.5 \mathrm{~cm}$ is regarded as cut off value for the Indians. Values of $18.5 \mathrm{~cm}$ represent moderate under nutrition and $16.0 \mathrm{~cm}$ represents severe under nutrition [6].
Waist-Hip Ratio: This was estimated by dividing the waist circumference by hip circumference. The limit of WHR was $\geq$ 0.85 for women and $\geq 1.00$ for men, above which superior distribution of adipose tissue was deemed [6].

\section{Dietary Assessment:}

Dietary surveys were done by the 24 hour recall method (oral questionnaire) where a set of standardized cups matched to local condition were used. Information on the total amount of each preparation is noted in terms of standardized cups and all the data were statistically evaluated. The calorific and nutritive values of different food-stuffs consumed by the employees were estimated using the tables of nutritive value of Indian food and compared with the quantity of the Recommended Dietary Allowance (RDA) for the Indians by ICMR 2010 [7, 8]. The survey was carried out during a period of 60 days.

\section{Statistical Analysis:}

The experimental results were expressed as the Mean \pm Standard error of mean (SEM). To test the significance of difference of different parameters, the Student's t-test was performed. Difference was considered significant when $p<0.05$.

\section{Results}

\section{SOCIO-ECONOMIC STATUS}

From the present study, it was seen that $95.25 \%$ of tribal women were illiterate (Fig-1). Most tribal women could not sign their name and were unable to read the newspaper. Only $4.75 \%$ tribal and $14.25 \%$ non-tribal women were educated up to primary level but have forgotten alphabets now. About $6.5 \%$ of the women had reached to junior high level, but they could not continue their study up to secondary level.

In this study, it was observed that nearly half of the women were tribal and $78 \%$ women were married. About $69 \%$ of non tribal female workers had 3-5 family members, but most tribal female workers owned big family size having 5-7family members. Only $32 \%$ women got jobs throughout the year in the brick field. At the same brick field most women workers' husbands were also employed. During the off season only $13 \%$ workers migrated to the nearby district to get better chances. From Fig-2, it is seen that $67 \%$ of the non-tribal female workers earned Rs. 2000$3000 /$ month whereas $72 \%$ of tribal women earned Rs 1000 $2000 /$ month. Women workers or their husbands were used to take loans from the owner to repair their home, for daughter's marriage, for treatment of the family members etc.

Figure 1. Educational status of Non tribal and Tribal female brickfield workers in Paschim Medinipur district.

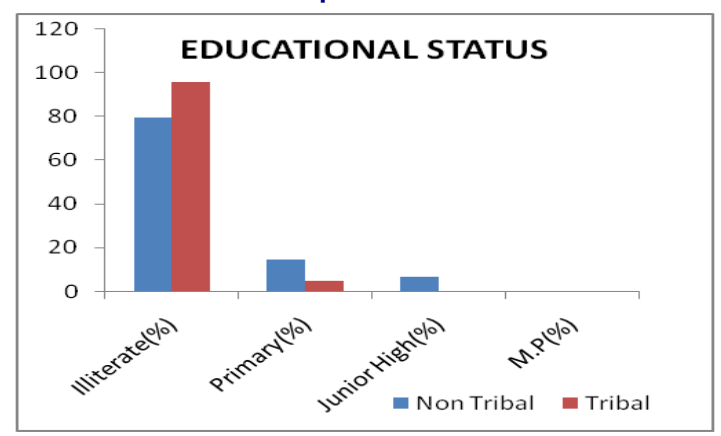


Figure 2. Monthly Income of Non tribal and Tribal female brick-field workers in Paschim Medinipur district.

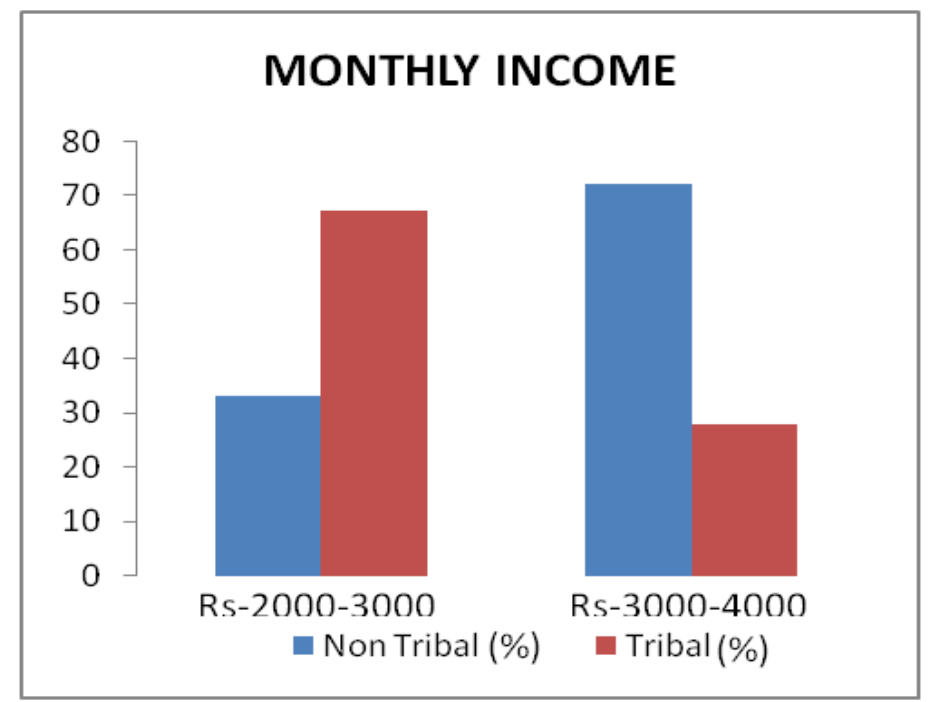

\section{MORBIDITY}

Figure 3 shows the morbidity profile of the non-tribal and tribal women workers where the pattern of disease is same but the magnitude is different. Musculoskeletal pain was the common morbidity among brick field workers. The morbidity profile shows that one fourth of the non tribal female workers are suffering from backache. Prevalence of anaemia among tribal (55.5\%) and non-tribal women $(49.2 \%)$ were more or less equal. Menstrual problem was seen more among tribal women (14.0\%) compared to non-tribal women (8.7\%). Open air defecation was common to all workers and safe food handling was not practiced by most women workers. Communicable diseases like fever, malaria, diarrhoea were prevalent among both tribal and non-tribal women. Migrant workers from other state like Bihar, Orissa were suffering from tuberculosis and leprosy. Skin diseases occurred significantly higher among the female tribal workers (8.2\%) compared to non-tribal females $(3.4 \%)$. Leg injury is significantly more in tribal workers $(21 \%)$ as well as in non-tribal workers $(29 \%)$.

Figure 3. Morbidity profile of female brick-field workers of Paschim Medinipur District.

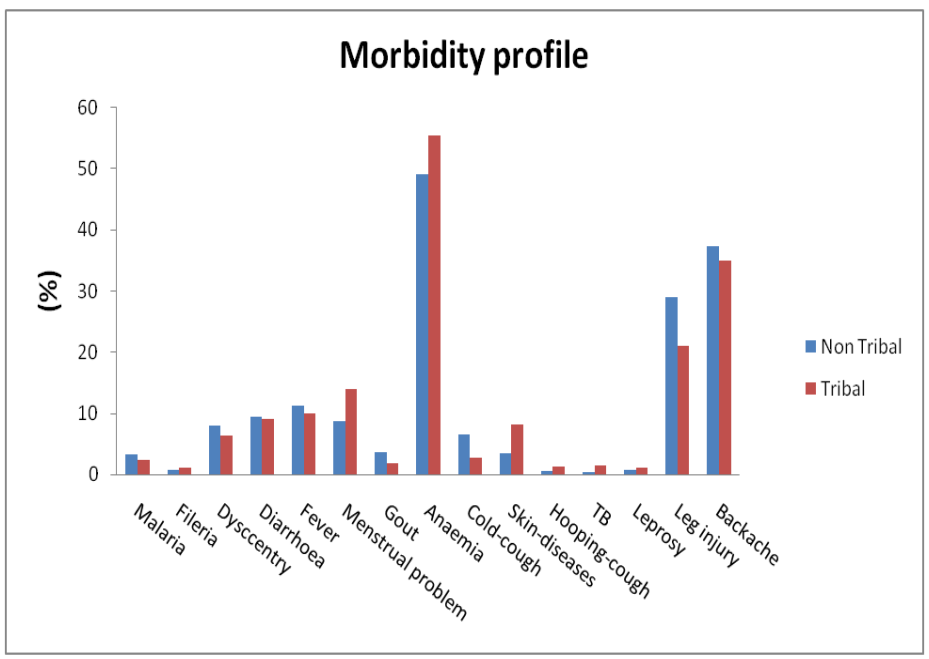

\section{ANTHROPOMETRIC STATUS}

Figure 4 shows that the mean heights of tribal and non tribal women workers were $150.47 \mathrm{~cm}$ and $150.83 \mathrm{~cm}$ respectively. Mean weight (Fig-5) of tribal women is only $40 \mathrm{~kg}$ and it is 41.7 $\mathrm{kg}$ in case of non tribal women. Both values are significantly lower $(P<0.01)$ than that of Indian standard value for adult woman which is $55 \mathrm{~kg}$ [9]. It is noteworthy that BMl of tribal women $\left(17.73 \mathrm{~kg} / \mathrm{m}^{2}\right)$ workers is significantly low $(P<0.01)$ compared to non tribal women workers $\left(18.35 \mathrm{~kg} / \mathrm{m}^{2}\right.$, Fig-6).

Figure 4. Height of Non-tribal and Tribal female brick-field workers of Paschim Medinipur District.

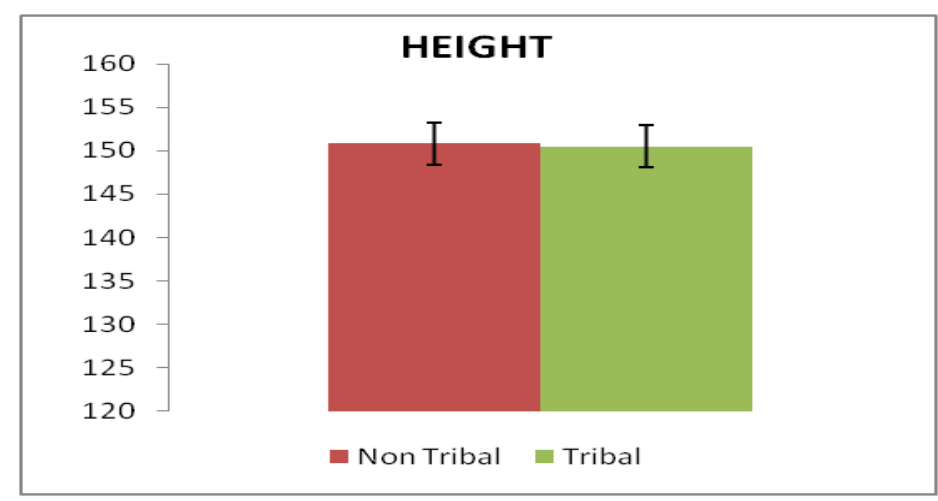

Figure 5. Weight of Non tribal and Tribal female brick-field workers of Paschim Medinipur District.

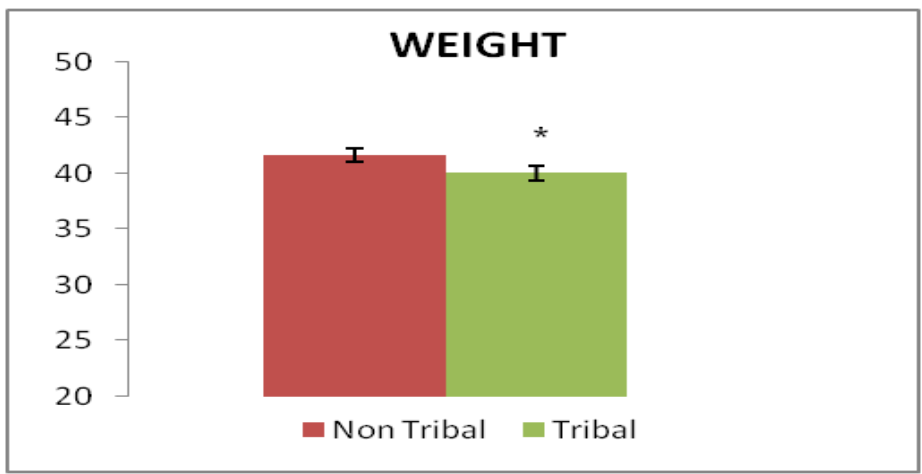

Figure 6. BMI of Non tribal and Tribal female brick-field workers of Paschim Medinipur District.

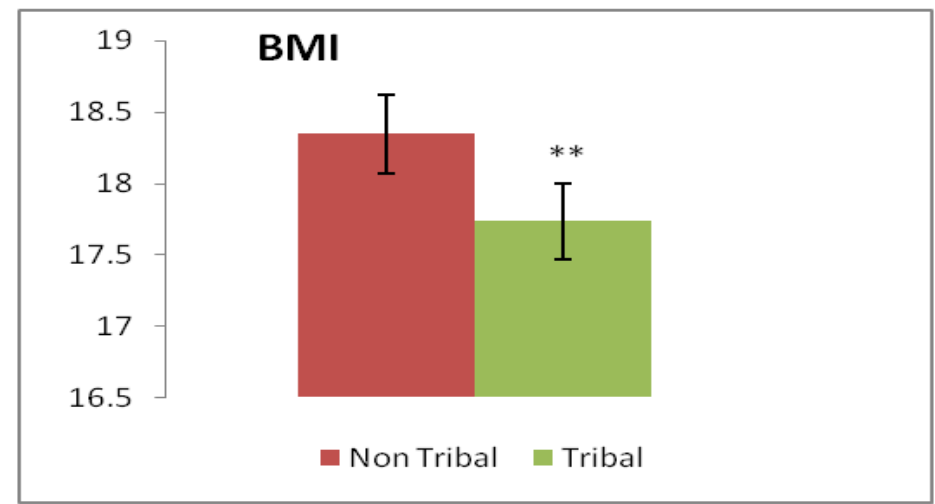

Figure 7 shows that mid upper arm circumference (MUAC) of tribal and non tribal women workers are $21.4 \mathrm{~cm}$ and $21.9 \mathrm{~cm}$ respectively. In both cases it is less than the Indian standard value of $22.5 \mathrm{~cm}$. The results also exhibit that the $\mathrm{W}-\mathrm{H}$ ratios of tribal women and non tribal women are less than the Indian 
standard value of 0.85 (Fig-8).

Figure 7. MUAC $(\mathrm{cm})$ of Non-tribal and Tribal female brick-field workers of Paschim Medinipur District.

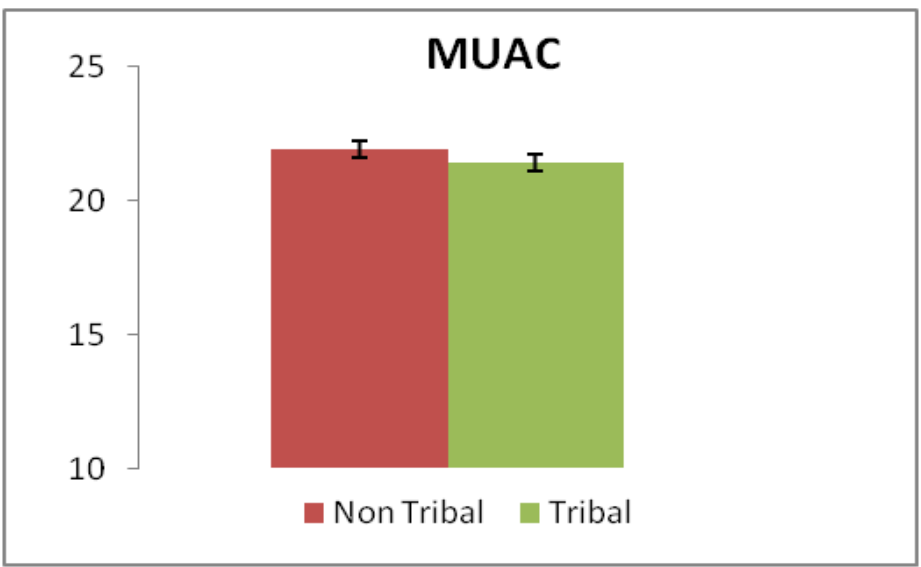

Figure 8. WHR of Non tribal and Tribal female brick-field workers of Paschim Medinipur District.

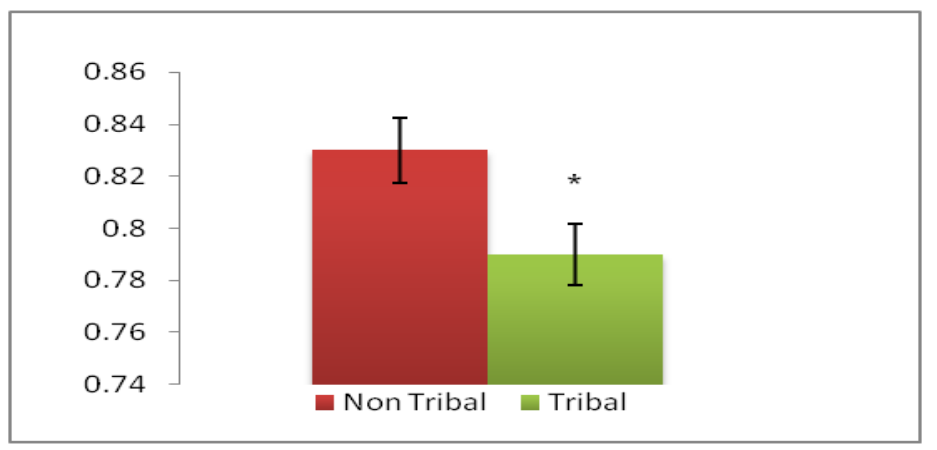

\section{NUTRITIONAL STATUS}

Energy consumption of tribal and non-tribal women from their diet were 1970 and $2053 \mathrm{Kcal}$ respectively, which is significantly less $(P<0.001)$ than ICMR RDA value of $2230 \mathrm{Kcal}($ Fig-9).

Table I : The dietary intake data of non-tribal and tribal brick field female workers in Paschim Midnapur district.

\begin{tabular}{|ccc|}
\hline $\begin{array}{c}\text { Name of taken } \\
\text { nutrient }\end{array}$ & $\begin{array}{c}\text { Non-tribal women } \\
\text { workers (Mean } \pm \text { S.D) }\end{array}$ & $\begin{array}{c}\text { Tribal women workers } \\
\text { (Mean } \pm \text { S.D) }\end{array}$ \\
\hline Energy (kcal/day) & $2053 \pm 21.01$ & $1970 \pm 20.89^{* * *}$ \\
\hline Carbohydrate (g/day) & $420.92 \pm 3.03$ & $404.74 \pm 3.54^{* * *}$ \\
\hline Protein (g/day) & $44.26 \pm 3.4$ & $43.64 \pm 3.28$ \\
\hline Visible Fat (g/day) & $17.31 \pm 2.3$ & $16.43 \pm 1.7$ \\
\hline Carotene( $\mu$ g/day ) & $2117.2 \pm 91.89$ & $1656.34 \pm 75.42^{* * *}$ \\
\hline Ascorbic acid (mg/day) & $39.29 \pm 2.9$ & $38.15 \pm 3.1$ \\
\hline Dietary fibre (g/day) & $3.89 \pm 0.78$ & $4.56 \pm 0.95$ \\
\hline Calcium (mg/day) & $299.1 \pm 12.79$ & $286 \pm 11.16$ \\
\hline Phosphorus(mg/day) & $777.46 \pm 5.7$ & $786.7 \pm 5.48$ \\
\hline Iron (mg/day)) & $18.89 \pm 1.89$ & $18.79 \pm 1.97$ \\
\hline Thiamin (mg/day)) & $1.19 \pm 0.156$ & $1.18 \pm 0.154$ \\
\hline Riboflavin (mg/day)) & $0.49 \pm 0.06$ & $0.48 \pm 0.06$ \\
\hline Niacin (mg/day) & $22.88 \pm 2.54$ & $18.94 \pm 2.97$ \\
\hline Folic acid ( $\mu$ g/day) & $97.81 \pm 9.71$ & $96.86 \pm 8.9$ \\
\hline
\end{tabular}

Table II: Average consumption of foodstuffs ( $\mathrm{g} / \mathrm{CU} / \mathrm{day}$ ) of nontribal and tribal brick field female workers in Paschim Midnapur district.

\begin{tabular}{|c|c|c|c|c|}
\hline $\begin{array}{l}\text { Name of } \\
\text { f?";/ood } \\
\text { stuff } \\
\text { t+utgfhcv } \\
\text { aken dailyv } \\
\text { (g/day) }\end{array}$ & $\begin{array}{c}\text { Food stuff } \\
\text { taken (g/day) } \\
\text { by Non-tribal } \\
\text { women } \\
\text { (Mean } \pm \text { S.D) }\end{array}$ & $\begin{array}{l}\text { Percent } \\
(\%) \text { less or } \\
\text { excess } \\
\text { compared } \\
\text { to RDA }\end{array}$ & $\begin{array}{c}\text { Food stuff } \\
\text { taken (g/ } \\
\text { day) by Tibal } \\
\text { women } \\
\text { (Mean } \pm \text { S.D)) }\end{array}$ & $\begin{array}{l}\text { Percent } \\
\text { (\%) less or } \\
\text { excess } \\
\text { compared } \\
\text { to RDA }\end{array}$ \\
\hline Cereals & $460 \pm 23.61$ & $39 \%$ extra & $450 \pm 24.50$ & $36 \%$ extra \\
\hline $\begin{array}{l}\text { Green leafy } \\
\text { vegetables }\end{array}$ & $25 \pm 7.59$ & $75 \%$ less & $30 \pm 3.77$ & $70 \%$ less \\
\hline $\begin{array}{l}\text { Other vege- } \\
\text { tables }\end{array}$ & $60 \pm 16.82$ & $70 \%$ less & $55 \pm 15.87$ & $72.5 \%$ less \\
\hline $\begin{array}{l}\text { Roots and } \\
\text { tubers }\end{array}$ & $110 \pm 20.48$ & $45 \%$ less & $105 \pm 19.45$ & $47.5 \%$ less \\
\hline $\begin{array}{l}\text { Milk and } \\
\text { milk product }\end{array}$ & $25 \pm 4.04$ & $92 \%$ less & $15 \pm 5.56$ & $95 \%$ less \\
\hline $\begin{array}{l}\text { Pulses and } \\
\text { beans }\end{array}$ & $20 \pm 3.54$ & $56 \%$ less & $18 \pm 4.17$ & $60 \%$ less \\
\hline Fish/meat & $25 \pm 2.78$ & $17 \%$ less & $22 \pm 5.79$ & $27 \%$ less \\
\hline
\end{tabular}

They consumed cereals adequately; thus carbohydrate consumption of tribal women and non-tribal women were 420.92 $\mathrm{g}$ and $404.74 \mathrm{~g}$ respectively (Fig-9). For these workers, rice was the main staple food followed by wheat. The protein intake in non-tribal and tribal women workers were 44.26 and $43.64 \mathrm{~g}$ respectively (Fig-9). It is significantly less than the ICMR recommended value of $55 \mathrm{mg}$ [7]. In tribal women average pulse intake was $18 \mathrm{~g}$ and in non-tribal women it was $20 \mathrm{~g}$ and the animal protein consumption was only twice or thrice in a week especially in some occasions. Non-tribal women consumed soya bean more than the tribal women. The visible fat intakes of non -tribal and tribal female worker were significantly less than the ICMR RDA of $25 \mathrm{mg}$ [7] (Fig-9). The carotene intake in tribal women and non-tribal women were 1656.34 and $2117.2 \mu \mathrm{g}$ respectively which are significantly less $(P<0.001)$ than the ICMR RDA value of $4800 \mu \mathrm{g}$ (Fig-9). Ascorbic acid consumed by tribal and non-tribal women was almost same to the ICMR RDA of $40 \mathrm{mg}$. The intake of dietary fibre in non-tribal and tribal women were 3.89 and $4.56 \mathrm{~g}$ respectively which is significantly less than the standard ICMR RDA as green leafy vegetable consumption was completely inadequate. Fig-9 also showed that calcium consumed by tribal and non-tribal women was 286 and $299.1 \mathrm{mg}$ respectively. It is significantly less $(P<0.001)$ than ICMR recommended value of $600 \mathrm{mg}$ [7]. The consumption of phosphorus by tribal and non-tribal women from their daily diet was 786.7 and $777.47 \mathrm{mg}$ which are greater than the Indian RDA value of $600 \mathrm{mg}$. The iron intake by tribal and non-tribal women from their daily diet was 18.79 and $18.89 \mathrm{mg}$ respectively (Fig-9). It is significantly less than the ICMR RDA of $21 \mathrm{mg}$ [7]. Thiamin and niacin consumed by tribal and 
non-tribal women from their daily diet were greater than the Indian RDA values. The intakes of riboflavin and folic acid by women workers were also significantly less $(P<0.001)$ than the Indian RDA value.

From the Table II, it is seen that only the cereal consumption was more in both group of female workers but intake of green leafy vegetables, other vegetables and pulses and beans by them were markedly less. It was also observed that milk and milk product consumption was prominently less.

Figure 9 shows the intake of nutrients as \% of RDA of non-tribal and tribal female brick-field workers. From the figure it is noteworthy that the female brick-field workers consumed folic acid, carotene, calcium, dietary fibres below $50 \%$ less than their ICMR RDA.

Figure 9. Intake of nutrients as \% of RDA of Non-tribal and Tribal female brick-field workers of Paschim Medinipur District.

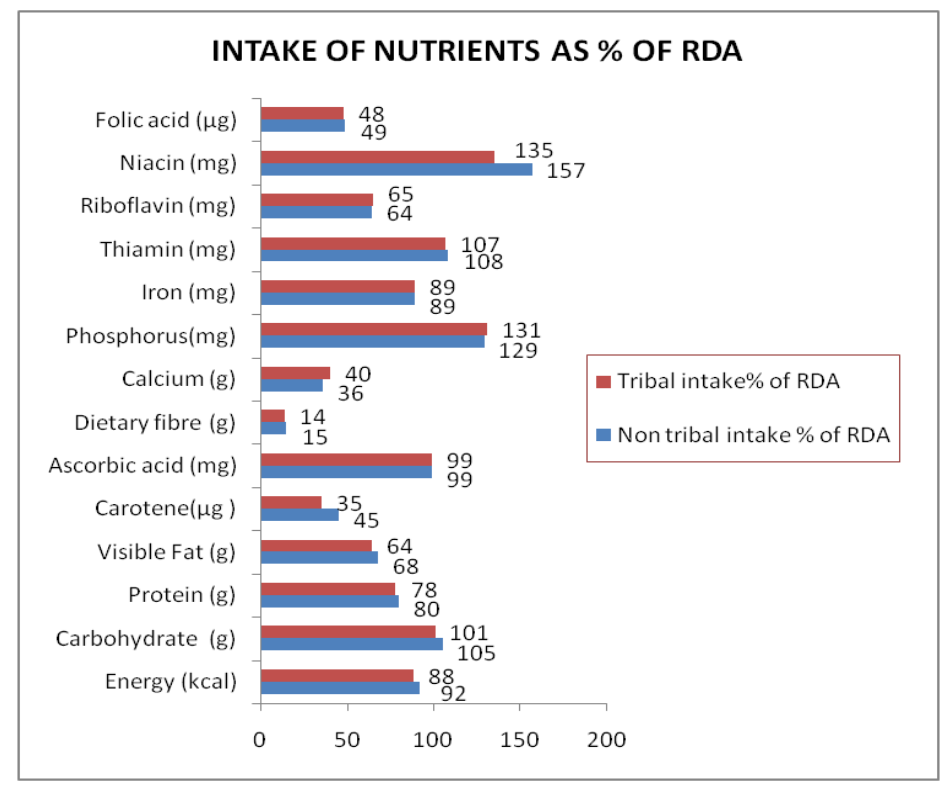

\section{Discussion}

Education is indispensable for the country's holistic growth and is an essential input in human resource development. In India, the rural literacy levels have been improved at the rate of one percent per annum at last 50 years [10]. According to census of India in 2001, literacy rate of rural women was $46.58 \%$ and in 2011 , it was $58.75 \%$. From the present study, it was seen that $78 \%$ non-tribal and $95.25 \%$ tribal women were illiterate and the educational status of non-tribal women was significantly higher compared to the tribal women (Fig-1). Only $4.75 \%$ tribal and $14.25 \%$ non-tribal women were educated up to primary level. In a similar study on brick industry, this type of illiteracy has been reported [4]. Higher literacy rate of non-tribal women is related to the development of a number of socioeconomic indicators like low birth rate, low infant mortality rate (IMR) and increase in life expectancy. Tribal female children do not go to school may be due to their poverty, early marriage, family tradition, etc. Women workers carried their children with them to the job places. These children also help their mothers and afterward they used to turn brick field workers. Some brick field workers migrate from one brick field to another or to distant places from where their children become unable to go to school and they become drop out student. These traditions are continuing generation after generation. The husbands of the non-tribal women workers are more educated than the tribal. Even now the language is also a barrier to tribal to get higher education because it is not their mother tongue. These brick field women in their girlhood were used to look after her brothers and sisters at their home and got married at their very early pubertal age.

Our study revealed that the wages of tribal and non tribal women were below the daily wages given in MGNREGS 2005 projects under Government of India and this was also reported earlier [4, 9]. Practically for the same work nowhere equal wages were paid to men and women. In the peak season they got the job every day, but in the off season this was not happened. Hence there were uncertainties and disparities in income among the brick field workers. They were overworked by the contractors, especially during the peak season. Tribal women were less interested to appeal to increase their salary.

The health of women is directly linked to their status in the society. Generally, at household level, socio-economic factors and cultural norms and practices determine the extent of health and nutritional status [9].Tribal women have better muscle power than non-tribal women and have an inherent ability to resist some disease. Female brick-field workers generally suffer from musculoskeletal pain because of their continuous standing at work place, forward bending for weight lifting and long working hour [11]. They had to work throughout in the sun, in the rain and in the cold for their job. The non-tribal and tribal female workers suffered significantly greater from leg injury and backache. They hardly got any off day at the weekend. The dust particle and smoke of the brick field generally enter through the respiratory tract and cause bronchial asthma, chronic cough etc. $[12,13]$. In our present study, it was also observed. They were not interested to take any safety measure to reduce occupational hazards. Tribal women are less health conscious than non tribal women. Some brick field workers stay far away from their home in unhygienic, unprotected area nearer to the workplace, where there is scarcity of drinking water, separate bathroom, kitchen and shelter. The oral hygiene of tribal worker is bad compared to the non tribal female worker. The prevalence of morbidity such as fever, anaemia and menstrual problems was relatively higher among them compared to the general population, indicating the problem of poor environmental sanitation and personal hygiene. Iron deficiency anaemia is widespread among rural women in India [14]. A woman becomes anaemic because of excessive blood loss during menstruation, chronic diarrhoea, malaria, hook worm infestation, early marriage with pregnancy, malabsorption and inadequate diet of low iron content [15]. World Health Organisation statistics indicate that worldwide prevalence of anaemia is about $30 \%$ with higher rates in developing countries like India [16]. According to NNMB surveys, in India, $24.4 \%$ of males 
and $21.8 \%$ of females suffer from anaemia [17]. Anaemia affects the work efficiency as the anaemic persons become exhausted easily. The children of the women workers had to stay with their mother at work places and also suffered from the same type of communicable diseases as seen in other pollution study [18].

Unremitting undernutrition throughout the growing phase of childhood leads to short stature in adult female workers. The prevalence of underweight $(<45 \mathrm{~kg}$ ) among women is about $60 \%$ in South Asia, around 45\% in South East Asia [10]. Where the reliability records of age are not available, the $\mathrm{BMI}$ is found to be most useful for assessment of nutritional status of the women workers, particularly tribal. In case of tribal women the incidence of chronic energy deficiency (CED) is greater than non tribal women. In India about $33 \%$ of adult men and $36 \%$ of the women have a Body Mass Index (BMI) below 18.5, which indicates Chronic Energy Deficiency or CED [19]. In India 44.90 percent women suffering from chronic energy deficiency as on 20052006 report [20]. The tribal women were particularly vulnerable to under nutrition compared to non-tribal women in rural areas. In India the prevalence of chronic energy deficiency (CED) was higher (56\%) among tribal non-pregnant, non-lactating women compared to rural women (36\%) [9]. The present study revealed that both tribal and non-tribal female brick-field workers are suffering from grade I chronic energy deficiency (CED I). It is well known that below $22.5 \mathrm{~cm}$ MUAC is a cutoff in the range commonly taken to be prognostic of low birth weight and also connected to moderate malnutrition [15]. Tribal women show greater occurrence compared to non-tribal women to have MUAC value less than $22.5 \mathrm{~cm}$. In our study, it was observed that mid upper arm circumference (MUAC) of tribal and non-tribal women workers are $21.4 \mathrm{~cm}$ and $21.9 \mathrm{~cm}$ respectively which are less than the Indian standard value of $22.5 \mathrm{~cm}$.

Carbohydrate contributes nearly $75 \%$ of their daily diet. The cereal intake by both tribal (36\% excess) and non-tribal $(39 \%$ excess) women workers remains satisfactory, but the pulse intake is only nearly $40 \%$ of the recommended value of ICMR. Intake of milk and milk products were $92 \%$ and $95 \%$ less compared to RDA in case of non-tribal and tribal female brick-field workers. These are correlated to CED I in non-tribal and tribal female workers which may also lead to protein energy malnutrition causing negative nitrogen balance. So they may be more susceptible to be suffering from infection because of low antibody production that hampers overall growth. Women who have poor health and nutrition are more expected to give birth to low weight infants [9]. The oils used by them are mostly mustard oil and rapeseed oil. The animal fat like butter, ghee is not taken by tribal women. They are not obese due to their low fat intake and long strenuous physical work.

The nutrient intake was observed to be below the RDA with respect to all nutrients except for phosphorus, niacin and thiamin. Inadequate intake of green leafy vegetable and improper method of cooking causes vitamin A deficiency in their diet. Low vision, night blindness, cataract is the common problem of low vitamin A intake and also they are unaware, neglecting to these problems. Consequently, they are susceptible to be suffering from degenerative diseases with increased risk of morbidity and mortality. They take locally available citrus fruit, guava, and vegetables nearer to brick field or kitchen garden and thus protected from scurvy, common cold. They don't purchase any fruit item from the market as it spends money. The consumption of green leafy vegetable is significantly less as it takes greater time to process and as a result, susceptible to be suffering from constipation, hypertension, diabetes mellitus, irritable bowel syndrome, colon cancer, etc. Vegetable consists of locally available green along with roots and tubers in their kitchen garden. Consumption of green leafy vegetable is greater among low income group. Both tribal and non-tribal women did not consume fish or meat properly. Tribal women used to take better amount snail in their daily diet compared to non-tribal women. Rice water taken by them, is a rich source of water soluble vitamin and if it is discarded the loss of vitamin occurred. Cereal based diet without the protective pulses and milk lead to riboflavin deficiency. Riboflavin deficiency also can occur whenever there are chronic infections. Good source of riboflavin is milk, but women did not consume milk as they believe that milk is needed for their children. In the morning some tribal worker takes raw tea with sugar without milk. Poor intake of milk, fresh fruit and vegetables also causes folate deficiency and it is the cause of anaemia [7].

\section{Conclusion}

In the brick field industry the condition of women, particularly tribal is very poor. Most of the women workers were illiterate. Some had studied up to the primary standard, while very few percent had passed the junior high level. Negligibly small proportion had passed the ninth class. Female workers of non tribal and tribal groups engaged in this industry are living below the poverty line and showed poor economic status. Equal access to education for women and girls has to be ensured. Special measures must be taken to eliminate discrimination, eradicate illiteracy and improve the quality of education to facilitate lifelong learning as well as development of skills of women. They are unaware of the different health schemes of government like vaccination, contraception, maternity and child health care and good quality food preparation practices. Malnutrition among women is a problem that has perhaps been under-recognized, and should now take greater priority. Awareness programs, including health counseling are essential for their overall holistic development.

\section{References}

1. Gulati L. Female Labour in the Unorganized Sector: Profile of a Brick Worker. Economic and Political Weekly, 1979; 14(16): 744.52.

2. Gulati L and Gulati M. Female Labor in the Unorganized Sector: The Brick Worker Revisited. Economic and Political Weekly, 1997; 32(18): 968.71. 
3. Mehta R. Morbidity profile of brick clin workers around Ahmedabad city. GujratDr.Rajesh Mehta health line. 2010;1(1): 41-44.

4. Shewale A. Nutritional and morbidity profile of brick Kiln workers in Sakwar, Tribal area of Thane District. Medical journal of western India, 2013; 41(1).

5. Lohman TG, Roche AF \&Martorell R (Editors) Anthropometric Standardization Reference Manual. Human Kinetics Books, Champaign (Illinois). 1988.

6.WHO. Physical status: The use and interpretation of anthropometry. Geneva: WHO, 1995.

7. Expert Group of ICMR. Recommended Dietary Intakes for Indians.New Delhi: Indian Council of Medical Research, 2010.

8. Gopalan C, Ramasastry BV, Balasubramanyam SC, NarasingaRao BS, Deosthale YG, Panth KC. Nutritive Value of Indian Foods. Hyderabad: National Institute of Nutrition (ICMR). 1990.

9. Rao KM, Balakrishna N, Arlappa N, Laxmaiah A and Brahmam GNV. Diet and Nutritional Status of Women in India. National Institute of Nutrition, (Indian Council of Medical Research), J Hum Ecol, 2010;29(3): 165-170.

10.Shramshakti: Report of the National Commission on Self-Employed Women and Women in the Informal Sector. New Delhi: Government of India. Survey of Socio-Economic Conditions of Women Workers in Unorganized Industries. New Delhi: Labour Bureau, Ministry of Labour. 1988.

11.Scwartz J. Air pollution and hospital admission for respiratory disease. Epidemiology, 1996, 7(1); 2028.5.

12.Bandyopadhyay A, Chatterjee S. Body composition, morphological characteristics and their relationship with cardio respiratory fitness. Ergonomics SA. 2003; 15:19-27.

13.Bobak M. Outdoor air pollution, low birth weight and prematurity, environmental health perspective, 2000;108:173176.

14.National Family Health Survey-3, International Institute for population on sciences, Mumbai, (2005-06).

15.Park JE, Park K. Environment and Health. In: Hamilton P, editor. Text book of Preventive and Social Medicine. 1989 ; 12th Ed.

16.Agarwal KN.. The effect of maternal Iron deficiency on the placenta and fetus. In: DB Jellife, EF Jellife (Eds.): Advances in International Maternal and Child Health.Oxford: Oxford University Press. 1984;4 ${ }^{\text {th }}$ Ed:26-35.

17. Health Information of India, Gol, Central Bureau of Health Intelligence, Directorate Non tribal of Health services, Ministry of Health family welfare, Nirman Bhavan, New Delhi. 2004.

18.Pope CA, Dockery DW, Acute health effects of PM10 pollution on symptomatic and asymptomatic children. The American review of respiratory disease, 1992; 145:1123-1128.

19.WHO, Worldwide prevalence of anaemia: WHO global database on anaemia(1993-2005).

20.Diet and Nutritional status of population and prevalence of Hypertension among adults in rural areas. NNMB Technical Report No: 24, NNMB, NIN, ICMR, Hyderabad. 2006.

\section{Acknowledgement}

The authors are thankful to Vidyasagar University, Midnapore for providing all the facilities to execute these Studies. 